\title{
Discussion on Practical Teaching Mode in the Classroom Teaching in Art and Design of Colleges and Universities
}

\author{
Qiku Bao \\ Jilin Animation Institute \\ Jilin, China
}

\begin{abstract}
With the development of social economy, people's aesthetic and other spiritual level requirements are also increasing, so it brings higher requirements and challenges to students majoring in environmental art design and relevant professional teachers. In order to meet the development needs of society, colleges and universities should be market-oriented, and focus on practical ability of students in the teacher of environmental art design, so as to cultivate personalized creative talents. Therefore, colleges and universities shall transform their teaching of environmental art design into the practice mode. The paper has analyzed the actual situation and problems in the teaching of environmental art design in colleges and universities based on current social situation and the attribute of environmental art design, accordingly emphasized the importance of the practical teaching mode and made some recommendations.
\end{abstract}

Keywords-environmental art design; practical teaching; necessity

\section{INTRODUCTION}

Environmental art design is a practical art design course. It is to plan and design people's living environment (indoor and outdoor environments) to build different styled indoor and outdoor environments by art design method in line with people's aes thetic demand. With the improvement of people's living standards, people's artistic and aesthetic demands for indoor living environment have been gradually improved, and therefore, as environmental art design talent cultivation base, colleges and universities should closely follow the trend of the times, grasp the changes in the market, and cultivate innovative talents at the needs of society. In this context, colleges and universities should not stick to the traditional classroom teaching mode of money see, money do in the teaching course of environmental art design, but should be in line with the market and society and take practice as primary and students as teaching subject, and focus on cultivating student's independent innovation thinking, so that students can skillfully use the knowledge and have strong practical ability and creativity. To achieve this goal, colleges and universities should adjust the setting of teaching system, promote teachers to reform teaching mode, and meanwhile give appropriate material support.

\section{CHARACTERIST ICS OF ENVIRONMENT AL ART DESIGN IN COLLEGES AND UNIVERSIT IES}

\section{A. Timeliness}

As a practical art, the environmental art specialty has a strong time liness, so it is the driving force of this specialty to cultivate talents at the needs of social development, but also the primary goal and premise for specialty construction. Based on this characteristic, colleges and universities should cultivate environmental art design talents according to social needs, meanwhile, they can predict social needs, and then shoot the arrow at the target and develop appropriate talent training system.

\section{B. Comprehensiveness}

Environ mental art design is a multidisciplinary integrated comprehensive discipline. Students majoring in this subject shall not only learn knowledge of fine arts but also shall grasp decoration, color match, computer technology and etc. Colleges and universities should cultivate environmental art design talents with wide scope of knowledge, strong comprehensive quality and sorting thinking ability, which shall be included into key points for specialty construction.

\section{Creativity}

For students majoring in design, creativity is undoubtedly the core competitiveness. You can even say that creation is the soul of design. Therefore, creativity is one of the indispensable characteristics of environmental art design. When colleges and universities carry out environmental art design teaching, they should pay particular attention to the cultivation of students' creative thinking. Based on the teaching ideas of guiding and liberating student's creativity, they should fully mobilize the initiative of students and establish students with a sense of innovation.

\section{Adaptability}

The scope of environmental art design is extensively wide, involving in built environment, indoor environment and environmental landscape design. Environment art designers are going to face almost all fields. Consequently, this specialty has higher requirements on designers' scope of 
knowledge and knowledge structure. It requires designers with considerable ability to adapt to such a social role. Therefore, colleges and universities should enhance students' basic knowledge, broaden students' professional knowledge, and cultivate students' adaptability in talent cultivation.

\section{THE CURRENT SITUATION AND PROBLEMS IN THE} TEACHING OF ART DESIGN IN COLLEGES AND UNIVERSITIES

\section{A. The Stale Teaching Content That Can't Meet the Needs of the Society}

The environmental art design specialty has the time liness. That is to say, the learned knowledge should follow the social aesthetic trend. However, the teaching content of many colleges and universities disconnects with market demand. Learned knowledge can not reflect the newest and most cutting-edge research achievements of this specialty, resulting that students have single knowledge without vividness and have difficulty to apply what they have learned, let alone to meet the social needs.

\section{B. Too Traditional Teaching Mode That Stresses Theory and Despises Practice}

At present, many colleges and universities still use the traditional teaching mode in the teaching of environmental art design. They stress students' theoretical knowledge learning and are less focusing on the practice of skills. Teachers still use textbooks as main teaching content. The teaching mode mainly is the old routine that teachers speak and students listen, which is almost empty talk. It not only makes classroom boring but also reduces student's learning interest and desire. Under the continuous development of the society, the weaknesses and limitations of this traditional teaching mode are increasingly apparent. It lacks practice in the teaching link, resulting that the trained students only have theoretical knowledge and lack practical ability. The teaching mode of monkey see, monkey do makes students greatly depend on teachers. With the passage of time, students become passive in learning and poor in subjective initiative, which is not conducive to the cultivation of students' creative thinking and severely inhibits the students to use their imagination to carry on the independent innovation.

\section{The Limitations of the Teaching Evaluation System in Colleges and Universities and the Lack of Teachers' Team}

The evaluation made by the teaching evaluation system is relatively comprehensive in colleges and universities. The evaluation on teachers consists of more than teaching. Teachers shall not only complete classroom content but also shall complete assigned educational administration tasks. They even shall submit the teaching plan of some skilloriented courses. In such an evaluation system, teachers are enslaved to paper writing, professional title evaluation and many other non-teaching works. It is difficult for them to spare too much energy for teaching and research. In addition, teachers are divorced from social practice for a long term. They can only be confined to the theoretical knowledge.
Furthermore, the selection of teachers for teaching environmental art design in colleges and universities is mainly based on their academic level. The majority of teachers for environmental art design works as a teacher just after their graduation, so they lack social practice experience. Naturally, it results that their teaching content mainly are theoretical and lack of practical operation.

\section{THE IMPORTANCE OF PRACTICAL TEACHING MODE IN THE TEACHING OF ENVIRONMENTAL ART DESIGN IN COLLEGES AND UNIVERSITIES}

As an applied design specialty, creativity and skills are extremely important. Skills and creativity only can be obtained by continuous experience and practice. Therefore, in the professional teaching of environmental art design, practice is a vital link. Due to its comprehensive characteristic, students of this major should master extensively wide scope of knowledge, including mature theoretical knowledge and accumulated practical knowledge. Whether the mastery of theoretical knowledge and accumulation of perceptual knowledge, or hands -on skills for shaping artistic image, they are inseparable from the practical operation. Practical teaching is the way to transform the theoretical knowledge into practical skills, which is an important way to improve students' practical ability and inspire their innovation ability. Therefore, the practice is essential in the teaching of environmental art design. The practical teaching can help students follow social demand. By implementing practical teaching students can explore problems, think about problems and solve problems independently, thereby activating students' creative thinking and cultivating them into truly high-quality talent of environmental art design.

\section{Discussion ON THE PRACTICAL TEACHING MODE IN THE TEACHING OF ENVIRONMENTAL ART DESIGN IN COLLEGES AND UNIVERSITIES}

At present, the traditional mode for teaching environmental art design in colleges and universities has not adapted to the needs of social development. It is very necessary to reform the teaching mode. The practical teaching mode should be carried out into professional teaching. The reform includes curriculum setting, teacher allocation, teaching goal setting and so on.

\section{A. To Develop Applied Design Talents as Teaching Goal}

First of all, the specialty of environmental art design involves relatively wide industrial fields. This professional talent should meet the needs of the market. Therefore, colleges and universities should subdivide the professional direction based on job classification and characteristics, clear the talent cultivation positioning, help students of this major involve in this occupation and enhance the competitiveness of professional graduates.

Second, in the people-oriented premise colleges and universities should stress students' personal characteristics and correctly guide their interests and hobbies. They can use the stage teaching goal of "big foundation and small 
direction" to cultivate students with personality. This means that what students learned in primary stage is a large professional foundation. With the mastery of fundamental skills, students can select a relative subdivided professional direction according to their characteristics and interests. It can not only excavate student's potential and stimulate students' learning enthusiasm, but also help students practice what they learned in the future.

Third, colleges and universities can cooperate with enterprises to provide students with practical platforms, tru ly achieving the combination of production, university and research. In the later stages of the teaching goal, the school can arrange students into cooperative enterprises or research institutes for post practice, which help students directly practice in real project. Students can practice with learned knowledge and learn from practice, which help students adapt to employment environment, apply their knowledge into practice, thus improving their self practical skill and increasing their actual combat experience.

\section{B. To Reform the Curriculum Setting Based on the Practical Teaching Mode}

First, from the teachers' teaching, the theory course is primary and the practice teaching is supplementary or even missing in the traditional teaching mode. In the practical teaching mode, the role of teachers is to guide and direct students, but not to instill knowledge. It plays a high value on students' principal status. Teachers mobilize the enthusiasm and initiative of students through guidance, and encourage students to explore and innovate. It first needs teachers to change their teaching ideas and accept and earnestly practice what they teach and adopt practical teaching mode.

It is now an era of picture view. For environmental art design, it should move audience with shape and meaning of the works. Therefore, in new teaching mode, teachers take practice as primary and teaching as supplementary. Teachers can introduce case into teaching and use multimedia, 3D projection and other advanced teaching methods to show students a large number of teaching materials and guide students through these materials, so that students can see various excellent works and pictures directly. In this way it not only arouses students' strong interest on class but also makes class lively and interesting. At same time, it is the quickest and most direct way for students to understand the market and experience the true meaning of environmental art design.

The student-oriented mode does not mean to let them alone. In the practical teaching mode, students should clearly be aware of their own value. Teachers can not leave students on their own but to actively play a leading role. It also has higher requirements on lesson preparation of teachers. To fully mobilize the initiative of students, the content in teachers' preparation lesson shall be rich: first, the arrangement of class hour should be reasonable and systematic. The time for three links, including theoretical explanation, practice and internship, shall be just right. Second, thoroughly understand teaching materials, know key points and difficulties of each chapter, create and set scene and task close to life reality and link learned knowledge with real life. The tasks should be progressive and operational, so that students can get a sense of achievement. Third, design course content according to students' actual situation and reach the purpose that students of each level are interested in it and can practice by themselves. In this process, teachers should pay close attention to students with poor initiative and foundation in order to avoid fishing in troubled waters and attending class passively. Teachers should drive students' initiative in learning by using this class mode, help student think independently while grasp theoretic knowledge and thus inspire their creativity.

Second, from the aspect of curriculum structure setting, the school should change the traditional unit system curriculum into project curriculum package. It means they should transform traditional unit system curriculum with textbook as standard into project organization curriculum. But it only can be carried out after students mastered basic knowledge. The school can classify real or virtual projects and put them into organized curriculum. In the leadership of the teachers, students are really involved in the project and practice themselves. Teachers give lessons in the frame of project in stages as needed, which can not only improve teaching efficiency but also can make the theoretical knowledge more vivid and help students play initiative and creativity better. Under such a curriculu m structure, teachers should not be confined to the classroom. Teachers can lead students out of the classroom, or find from daily life, or go to the real scene to practice, which not only can effectively mobilize the enthusiasm of students, but also allows students to learn practical skills in the experience, achieving the effect with half effort.

Third, from the teaching environment, in order to strengthen the practice teaching environment, the school can cooperative with enterprises, but also can establish the "studio system" teaching mode. Enterprise platform can be used for students to practice in the later stage, so that the students step into society as soon as possible and adapt to employment environment. It also allows students to explore in practice and inspires students' creative inspiration and enhances their professional skills. The teaching mode of "studio system" is a team-based organization teaching way. It is composed of instructors, experts, team members and students. They share out the work and cooperate with one another, communicate with each other and jointly complete organized teaching objectives and are leading to professional direction. It is a practice base for students, which can provide the opportunity to practice for students in the early or middle learning stage. The establishment of the studio is the basic guarantee of the practice teaching mode, for students can carry out all kinds of operations in the studio. It can improve students' hands-on skills, knowledge applications and other aspects of the practical skills.

\section{To Strengthen the Quality of Teachers with the Construction of "Double-Certificated Teacher"}

"Double-certificated teacher" means that teachers of environmental art design should not only have a teacher 
qualification certificate, but also a professional qualification certificate. It drives teachers to approach practice and promote professional teachers to participate in the practical creation. Environmental art design is a very practical major, with the characteristic of timeliness and frequent change of industrial information. In order to adapt to the development trend of the industry, the school teachers should also practice in enterprise, accumulate experience from personal practice, and truly become a double-certificated teacher. On the other hand, the school should urge the teacher to carry on the foreign exchange, encourage the teacher to carry on the specialized teaching research, thus strengthen the teaching reform and perfect the practical teaching mode. In this way they can achieve the effect of the combination of industry, university and research. Third, the school can invite wellknown professional designers as visiting teachers to deliver lectures and exchange, help students keep in touch with the new trend of the industrial development, expand the horizon s of students and improve students' vision.

The improvement of faculty power is the key to improve the teaching quality and the core of the cultivation of highquality talents. Therefore, the establishment of "doublecertificated teacher" teaching team has a decisive role in the practical teaching mode. As a result, colleges and universities should change the traditional teacher engagement standards, not only focus on the theoretical knowledge, but also pay attention to teachers' professional skills.

\section{CONCLUSION}

Environmental art design is an applied design specialty, so the practical link is essential in the course of the teaching process. Therefore, it is extremely urgent to implement practical teaching mode, and it requires the school, teachers and students to work together. The school provides the school-enterprise cooperation platform, "studio system" and new curriculum structure of project package. Teachers should transform their concepts, not only teach students basic theory knowledge, but also inspire students' independent thinking and creative thinking, meanwhile actively participate in social practice, so as to become a real designer through practice in the industry as well as a doublecertificated teacher. Students should correct learning attitude, and actively play their own initiative and participate in the practice. In short, the school should construct various platforms for teaching practice through various aspects of efforts, extend teaching out of classroom, and help teachers and students in touch with the first line of the industry to the full range through multi-channels. Teachers should actively participate in practical activities, so that they can combine theory and practice and integrate teaching and practice into one, thus develop high-quality design talents at the needs of society.

\section{REFERENCES}

[1] Liu Le, Yang Bingqing and Ou Chun, Thinking and Innovation on Teaching Mode of Environmental Art Design under New Situation, Modern Gardening, Issue 4, 2014
[2] Yuan Jing and Ji Changwu, Exploration and Research on Practical Teaching of Art Design under View of Creative Industry, Academic Exploration, September 2013.

[3] Zhai Xiaonan, Practical Teaching Reform of Environmental Art Design in Colleges and Universities, Journal of Shenyang Instit ute of Education, Issue 4, August 2012. 